\title{
IDENTIFIKASI STRUKTUR STOK IKAN BELIDA (Chitala spp.) DAN IMPLIKASINYA UNTUK MANAJEMEN POPULASI ALAMI
}

\author{
Arif Wibowo'), Mas Tri Djoko Sunarno'), Safran Makmur1), dan Subagja1) \\ 1) Peneliti pada Balai Riset Perikanan Perairan Umum, Mariana-Palembang \\ 2) Peneliti pada Pusat Riset Perikanan Tangkap, Ancol-Jakarta
}

Teregristrasi I tanggal: 9 Agustus 2007; Diterima setelah perbaikan tanggal: 9 Maret 2008; Disetujui terbit tanggal: 19 Maret 2008

\begin{abstract}
Penelitian ini dilakukan selama tahun 2006 di perairan umum Propinsi Riau, Sumatera Selatan dan Kalimantan Selatan. Tujuan penelitian ini adalah mendeterminasi struktur stok ikan belida (Chitala spp.) baik pada level inter maupun intra populasi dengan pendekatan morfologi dan genetik. Selanjutnya, menganalisis bagaimana implikasi dari kondisi struktur stok yang ada untuk manajemen dan konservasi spesies ikan belida (Chitala spp.) di alam. Lokasi pengambilan contoh ditentukan secara purposive sampling, dikoleksi 120 spesimen untuk pengukuran morfometrik meristik dan mitochondria-DNA. Pengukuran biometrik dilakukan pada 35 karakter morfologi bentuk badan, pada bagian sisi sebelah kiri tubuh ikan, untuk analisis DNA dilakukan dengan metode restriction fragment length polymorphism pada mitochondria-DNA menggunakan primer 16S rRNA. Analisis data biometrik dengan analisis deskriminan menggunakan software statistica 6.0, analisis mitochondria-DNA dengan analisis molekuler varians dan Fst dalam program Arlequin. Hasil penelitian menunjukkan berdasarkan pada analisis genetik terdapat 5 kelompok populasi ikan belida (Chitala spp.). Populasi Pangkalan Buluh adalah populasi yang unik, memiliki jarak genetik yang lebar dan terpisah dari populasi yang lain, populasi ini ditandai oleh karakter morfometrik AH dan ISL yang besar dan PPFL yang kecil dan nilai NVS yang besar dan NAFL yang kecil pada karakter meristik. Keragaman genetik populasi ikan belida (Chitala spp.) tergolong rendah dengan kisaran antara 0 sampai dengan 0,125. Konservasi ikan belida (Chitala spp.) terutama diprioritaskan pada populasi Kampar Kiri, Ogan, dan Kerinci, prioritas selanjutnya, adalah populasi Pangkalan Buluh (Sungai Musi). Upaya konservasi pada populasi Sungai Kampar Kiri, Sungai Ogan, dan Sungai Kerinci adalah dengan traslokasi atau restocking, sedangkan untuk Pangkalan Buluh adalah penetapan wilayah konservasi sehingga populasi dapat berkembang tanpa dilakukan kegiatan restocking. Data genetik juga menyediakan peta gen untuk perencanaan design persilangan untuk restocking, populasi sintetik dan program breeding ikan belida (Chitala spp.) di lokasi penelitian.
\end{abstract}

KATAKUNCl: $\quad$ ikan belida, struktur stok, morfometri, 16S rRNA mitochondria-DNA, konservasi dan manajemen

\section{ABSTRACT: $\quad$ Stock structure identification of knife fish (Chitala spp.) and its implication to manage the wild population. By: Arif Wibowo, Mas Tri Djoko Sunarno, Safran Makmur, and Subagja}

This reseach was conducted during 2006 at Province Riau, South Sumatera and South kalimantan open waters. The purpose of the study was to determine knife fish (Chitala spp.) stock stucture both intra and interspecific level using morphology and genetic approach and then giving research's recommendation in order how to manage the wild population of knife fish (Chitala spp.). Sampling locations selected base on purposive sampling, finally there were 120 specimen for morfometric, meristic measurement, and mitochondria-DNA analysis. Biometric measurement was conducted at 35 morphology characters, on the leftside of the fish's body, restriction fragment length polymorphism method was employed for mitochondria-DNA analysis with 16S rRNA marker. Biometric data were subject of discriminant analysis using statistica 6.0 package, mitochondria-DNA was analize with analysis molecular varians and genetic distance (Fst) in arlequen program. The results shown base on genetic analysis there are 5 groups of knife fish (Chitala spp.) population. Knife fish (Chitala spp.) from Pangkalan Buluh displayed unique population, this population has wide genetic distance and separate from others population, marked with bigger morphometric character of $A H$, ISL, and NVS meristic character, smaller of PPFL on morphometric and NAFL on meristic character. Genetic diversity of knife fish (Chitala spp.) was proved to be low in the range of 0 until 0.125 . For knife fish (Chitala spp.) conservation, the priority should be given on the population of Kampar Kiri Rivers, Ogan Rivers, and Kampar Kanan Rivers. The next priority was population Pangkalan Buluh. The appropriate conservation effort for population Kampar Kiri, Ogan, and Kampar Kanan is by translocation, meanwhile for Pangkalan Buluh in situ conservation will be the right choice without restocking program. Genetic 
data that were informed from this research could be useful on planning captive breeding for restocking, to make sintetic population, and succesfull breeding program of knife fish (Chitala spp.) on research site.

KEYWORDS:

knife fish, stock structure, morphometric, 16S rRNA mitochondria-DNA, conservation, management

\section{PENDAHULUAN}

Dampak manusia terhadap habitat alam secara nyata telah meningkat, sehingga terjadi ancaman kepunahan pada sejumlah species di dunia (Ryder et al., 2000). May et al (1994) memperkirakan tingkat kepunahan hewan dan tumbuhan pada masa yang akan datang, menjadi 4 kali lebih besar dibandingkan perkiraan berdasarkan pada analisis fosil, untuk itu, konservasi dan manajemen keragaman hayati menjadi tugas yang penting dan mendesak.

Konservasi dan manajemen perikanan di masa depan diarahkan pada identifikasi stok berbasis unit populasi bukan kelimpahan dan ukuran ikan yang dapat di panen. Alasannya, karena kelimpahan dan karakteristik populasi tidak dapat dipastikan secara sederhana di masa depan, dengan memilih keseimbangan yang tepat antara tangkapan dan recruitment untuk memaksimalkan tangkapan. Kemampuan bertahan hidup yang berbeda dan reproduksi ikan dengan genotip yang beda akan mengubah komposisi genetik dari populasi yang ditangkap (Allendorf et al., 1987). Identifikasi stok ikan saat ini telah menjadi suatu bagian yang penting dalam upaya manajemen sumber daya perikanan air tawar (Beacham et al., 1985a; Beacham et al., 1985b). Identifikasi stok ikan dapat dilakukan melalui pengukuran morfologi; morfometrik (Tschibwabwa, 1997; Sudarto, 2003; Gustiano, 2003) dan meristik (Seymour, 1959; Al-Hasan, 1984; MacCrimmon \& Clayton, 1985), dan marka molekular (Krueger, 1986; Waltner, 1988; Sudarto, 2003).

Spesies ikan belida (Chitala spp.) telah disadari memiliki arti penting bagi manusia sebagai sumber makanan (Kottelat \& Wijanarti, 2005), budaya (maskot daerah), dan ikan hias. Identifikasi stok ikan belida (Chitala spp.) sedikit diketahui di Indonesia baik pada tingkat inter maupun intra populasi, bahkan Kottelat \& Wijanarti (2005) mengatakan sampai dengan saat ini belum tersedia identifikasi yang valid untuk spesies ikan belida (Chitala spp.), paling tidak ada 2 sampai dengan 4 spesies Chitala lopis di Asia Tenggara (ke-4 ada di Indonesia). Sebelumnya, famili Notopteridae telah direvisi oleh Robert (1992b) yang mengatakan semua Chitala yang berasal dari Indonesia merupakan satu spesies, Chitala lopis.
Identifikasi yang dilakukan Robert, sebagian berdasarkan pada pola detil pewarnaan tubuh tidak sesuai dengan teori perubahan warna ontogenetic dari 1 spesies (Kottelat \& Wijanarti, 2005).

Tulisan ini bertujuan mendeterminasi struktur stok ikan belida (Chitala spp.) baik pada level inter maupun intra populasi dengan pendekatan morfologi dan genetik. Selanjutnya, menganalisis bagaimana implikasi dari kondisi struktur stok yang ada untuk manajemen dan konservasi spesies ikan belida (Chitala spp.) di alam.

\section{BAHAN DAN METODE}

\section{Pengambilan Contoh Ikan}

Penelitian ini dilakukan selama tahun 2006 di perairan umum Propinsi Riau, Sumatera Selatan dan Kalimantan Selatan (Gambar 1). Penentuan lokasi pengambilan untuk mendapatkan contoh spesimen ikan belida (Chitala spp.) dilakukan secara purposive sampling, pada daerah yang ada ikan belida (Chitala spp.). Ikan contoh diperoleh secara langsung di lapangan maupun melalui pedagang pengumpul, alat tangkap yang digunakan adalah pancing, jala, dan bubu. Berdasarkan pada pengambilan contoh dikoleksi 120 spesimen untuk pengukuran morfometrik meristik dan mitochondria-DNA.

Untuk setiap spesimen, sebagian jaringan sirip ekor (berukuran 1x1 cm2) dikoleksi, direndam dalam vialtube yang berisi larutan alkohol $75 \%$ dan diberi label kode dan asal spesimen, untuk kemudian disimpan dalam lemari pendingin. Untuk carcass, dikeluarkan isi perut dan ditandai (tagging) dituliskan kode dan lokasi asal spesimen dengan menggunakan dymo machine; contohnya RK 001. Contoh yang sudah ditandai selanjutnya diawetkan dengan cara direndam larutan alkohol $75 \%$ untuk identifikasi lebih jauh.

\section{Karakter Morfologi}

Pengukuran biometrik yang dilakukan adalah morfometrik dan meristik. Morfometrik adalah perbandingan ukuran relatif bagian-bagian tubuh ikan. Perbedaan morfologis antar populasi dapat berupa 
perbedaan seluruh ukuran dan bentuk, tetapi pada umumnya melibatkan ke-2 (Sprent, 1972). Perbedaan bentuk antar populasi ikan dikatakan sebagai fungsi ukuran (McGlade \& Boulding, 1985). Meristik adalah bagian yang dapat dihitung dari ikan yang merupakan jumlah bagian-bagian tubuh ikan, misal jumlah duri pada perut.

Pengukuran morfometrik spesimen dilakukan dengan menggunakan digital caliper yang memiliki ketelitian sampai dengan 0,10 mm, sedangkan meristik dilakukan penghitungan manual dibantu kaca pembesar. Metode pengukuran dengan menggunakan manual digital calliper adalah metode yang sampai dengan saat ini paling banyak digunakan dalam studi morfologi, paling tidak terdapat 31 dari 42 studi tentang subyek ini yang telah dipublikasikan (Schaeffer, 1991). Pengukuran karakter morfometrik dan meristik ikan belida (Chitala spp.) dilakukan pada 35 karakter morfologi bentuk badan (Gambar 2), pada bagian sisi sebelah kiri tubuh ikan. Karakter morfometrik diwakili oleh data yang tidak terpisah atau continous data. Meristik diwakili oleh data yang terpisah atau non continous data (Manly, 1989; Sokal \& Rohlf, 1995).

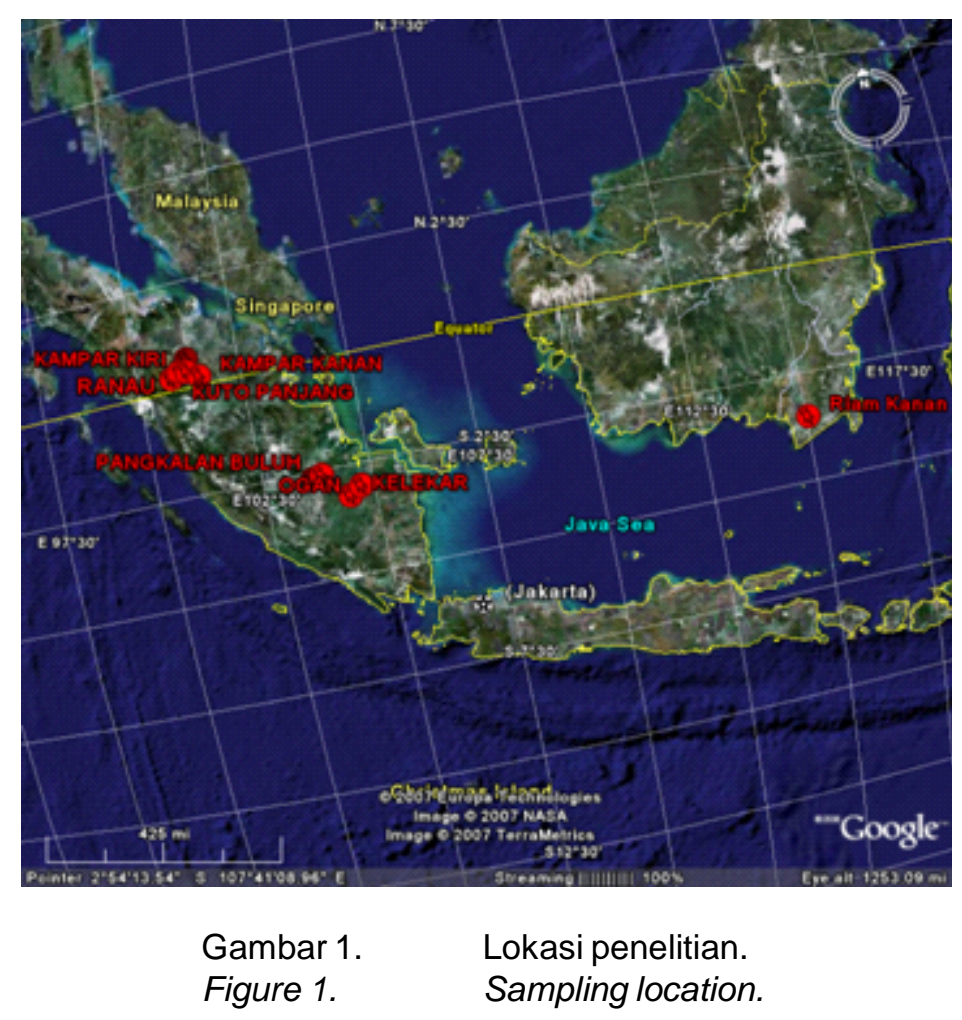

Tipe analisis data yang sangat cocok untuk ke-2 data ini adalah analisis deskriminan (Clyton \& Mac Crimmon, 1987; Schaeffer (1991), menambahkan analisis deskriminan merupakan teknik analisis statistik yang paling tepat untuk memisahkan 2 atau lebih kelompok yang sebelumnya telah diketahui. Analisis deskriminan adalah suatu proses untuk membedakan 2 atau lebih group yang teridentifikasi dengan kombinasi linear dari 2 atau lebih variabel (Fisher, 1936; Saraswati \& Sabnis, 2006). Dalam studi ini, teknik analisis deskriminan digunakan untuk

melihat tingkat kesamaan antara populasi ikan belida (Chitala spp.), yang dianggap sebagai 1 unit stok dan mengidentifikasi secara benar karakter morfometrik dan meristik. Selanjutnya, menggambarkan jarak genetik berdasarkan pada penghitungan mahalobis distance. Sebelum analisis dilakukan, data morfometrik distandarisasi dalam bentuk \% SL dan dinormalisasi dengan trasformasi $\log (x+1)$. Pengolahan data menggunakan paket program Statistica versi 6.0 . 

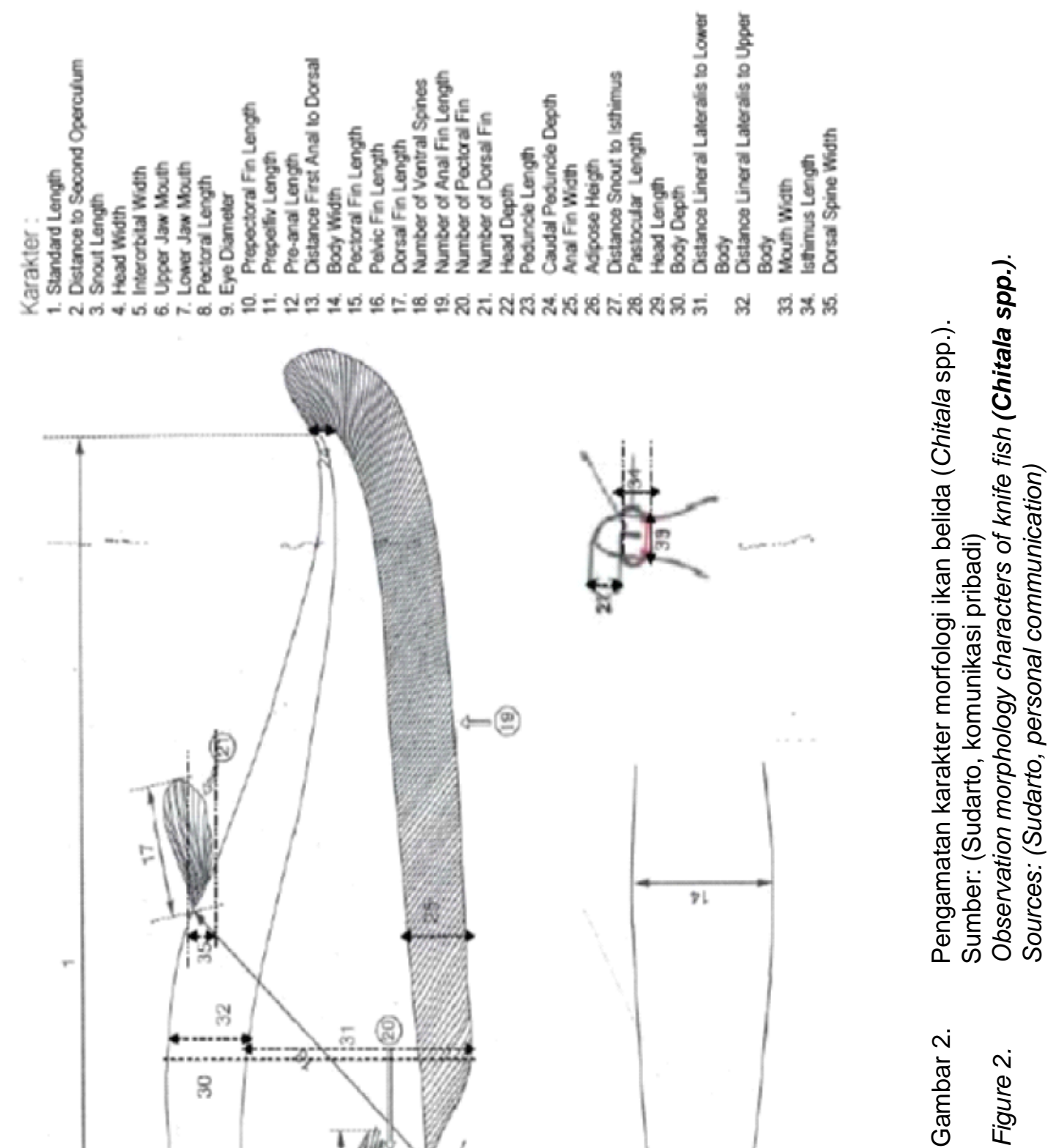


\section{Marka Molekular (mitochondria-DNA)}

Untuk mengetahui struktur stok ikan belida (Chitala spp.) pada level inter dan intra populasi dilakukan menggunakan gen mitokondria 16S rRNA. Metode genetik ini digunakan untuk topik yang berhubungan dengan identifikasi stok, zoogeografi, dan filogeni, karena mitokondria-DNA memiliki tingkat evolusi yang tinggi (5 sampai dengan 10 kali lebih besar dari DNA inti) (Brown et al., 1979; Brown, 1983). Genom mitokondria-DNA bersifat maternal dan diturunkan oleh parental tanpa rekombinasi, lebih sensitif pada genetik drift (Harrison, 1989; Amos \& Hoelzel, 1992) dan lebih cepat mendapatkan hasil dari jaringan yang telah diawetkan sebelumnya (Paabo, 1989) dibandingkan menggunakan genom DNA inti. Gen 165 ribosomal RNA mitokondria telah terbukti berguna dalam menggambarkan sejarah evolusi pada populasi hewan baik pada intra dan inter spesifik level (Sarver et al., 1998; Crandal et al., 1999).

DNA ikan diekstraksi dari potongan sirip ekor dengan menggunakan kit Wizard genome DNA purification (Promega), sebagai berikut 5 sampai dengan $10 \mathrm{mg}$ potongan sirip ikan dimasukkan ke dalam tabung $1,5 \mathrm{~mL}$ yang telah berisi $500 \mu \mathrm{L}$ larutan lisis DNA+120 larutan 0,5 M EDTA pH 8,0. Kemudian ditambahkan $10 \mu \mathrm{g}$ per $\mathrm{mL}$ protein kinase dan diinkubasi pada suhu $55^{\circ} \mathrm{C}$ selama 3 jam. $3 \mu \mathrm{L}$ larutan Rnase ditambahkan ke dalam campuran tersebut, kemudian diinkubasi pada suhu $37^{\circ} \mathrm{C}$ selama 30 menit. Setelah didinginkan pada suhu kamar, ditambahkan ke dalam larutan protein presipitation $200 \mu \mathrm{L}$ dan disimpan dalam es selam 5 menit. Kemudian disentrifus pada kecepatan 10.000 rpm selama 10 menit. Lapisan supernatan diambil dan dimasukkan ke dalam tabung baru, dan ditambahkan $600 \mu \mathrm{L}$ larutan propanol dan divortex sampai dengan terlihat endapan putih. DNA diendapkan dengan cara mensentrifus campuran tersebut pada kecepatan 10.000 rpm selama 10 menit, kemudian larutan di atas dibuang dan DNA dikeringkan pada suhu ruangan. Setelah kering ditambahkan 50 sampai dengan $100 \mu \mathrm{L}$ Tris-EDTA (TE) buffer dan disimpan pada suhu $4^{\circ} \mathrm{C}$ sebelum digunakan pada tahap selanjutnya.

Primer yang digunakan untuk mengamplikasi sequnce mitokondria adalah 16 sarRNA primer- $5^{\star}$ CGC CTG TTT AAC AAAAAC AT. 16sbr-3* CCG GTT TGA ACT CAG ATC AT GT. Amplifikasi menggunakan metode polymerize chain reaction dengan komposisi reaksi yang terdiri atas $10 \mu \mathrm{g}, 10 \mathrm{pmol}$ setiap primer dan pure tag DNA (Promega) dengan total volume keseluruhan $25 \mu \mathrm{L}$. Siklus polymerize chain reaction yang digunakan dalam amplifikasi adalah 1 siklus denaturasi pada suhu $95^{\circ} \mathrm{C}$ selama 2 menit. 35 siklus penggandaan yang terdiri atas $95^{\circ} \mathrm{C}$ selama 1 menit, $45^{\circ} \mathrm{C}$ selama 1 menit dan $72^{\circ} \mathrm{C}$ selama 2,5 menit. Selanjutnya, 1 siklus terakhir pada suhu $72^{\circ} \mathrm{C}$ selama 10 menit. Sequence mitochondria-DNA yang didapat direstriksi dengan menggunakan endonuklease sesuai dengan prosedur perusahaan. Hasil restriksi kemudian dipisahkan secara elekforesis dengan menggunakan gel agarose 2 sampai dengan 3\% dalam Tris-BoricEDTA bufferdan diamati dengan illuminator (UV) serta dicetak gambar dengan polaroid.

Susunan haplotipe ikan belida (Chitala spp.) pada masing-masing enzim restriksi dikumpulkan sebagai komposit haplotipe dan dianalisis dengan menggunakan analisis molekuler varians dan Fst dalam program ARLEQUIN (Schneider et al., 1996). Diversitas haplotipe atau diversitas gen dihitung berdasarkan pada Nei \& Tajima (1981) untuk mengamati tingkat variasi genetik yang ada. Kekerabatan antar populasi dianalisis dengan menggunakan jarak genetik (Da) berdasarkan pada Takezaki \& Nei (1996).

\section{HASIL DAN BAHASAN}

\section{Karakter Morfologi (Fenotipe)}

\section{Analisis morfometrik}

Analisis stepwise memperlihatkan bahwa 19 dari 31 karakter morfometrik memberikan kontribusi yang nyata terhadap deskriminan multivariat dari 7 populasi ikan belida (Chitala spp.) yang diamati (Tabel 1). Karakter morfometrik AH, PPFL, dan ISL memperlihatkan nilai indeks potensi yang lebih superior. Dapat dikatakan bahwa karakter tersebut adalah karakter utama yang membedakan 7 populasi ikan belida (Chitala spp.) yang diamati. AH dan ISL memperlihatkan nilai korelasi yang terbesar dengan fungsi canonical variate 1, sedangkan PPFL pada fungsi canonical 2. Populasi Musi (ikan belida (Chitala spp.) yang ada di Pangkalan Buluh dan Kelekar) dicirikan dengan nilai $\mathrm{AH}$ dan ISL yang besar dan PPFL yang kecil.

Tingkat pengelompokkan populasi dari prosedur klasifikasi pada 19 karakter diperkirakan berkisar antara 66,7 sampai dengan $100 \%$ dengan rata-rata $91,2 \%$ (Tabel 2). Berdasarkan pada analisis karakter morfometrik, populasi ikan belida (Chitala spp.) yang ada di Pangkalan Buluh (Musi) memiliki tingkat validitas yang paling besar. 
Tabel 1. Indeks potensi untuk variabel yang masuk dalam model, deskriminan loading dan keragaman data yang dijelaskan pada karakter morfometrik dan meristik

Table 1. Potency indeks for variable in the model, discriminant loading and variation in morphometric and meristic data

\begin{tabular}{cccc}
\hline Morfometrik/ & Indeks potensi/ & \multicolumn{2}{c}{ Muatan pembeda/Discriminant loading } \\
\cline { 2 - 4 } Morphometric & 0,589333 & CV1 & CV 2 \\
\hline ISL & 0,819580 & 1,10503 & 0,4656 \\
ED & 0,661387 & $-0,237$ & $-0,24432$ \\
SNL & 0,655788 & $-0,4792$ & 1,30594 \\
DSW & 0,509599 & 1,10485 & $-1,74693$ \\
AH & 0,518394 & 1,60529 & 0,52274 \\
PPFL & 0,800852 & $-1,446$ & $-1,37896$ \\
AFW & 0,666076 & $-0,5063$ & $-0,05472$ \\
PPL & 0,705371 & 0,49809 & 0,64161 \\
DLU & 0,790609 & $-0,2916$ & $-0,67957$ \\
DFD & 0,680409 & $-0,5409$ & 0,03107 \\
IOW & 0,719867 & $-1,2705$ & $-0,0972$ \\
MW & 0,780912 & 0,38992 & $-0,34045$ \\
HW & 0,816570 & 0,36268 & 1,24816 \\
PFL & 0,49925 & $-0,17758$ \\
DLB & 0,729529 & 0,24346 & 0,58101 \\
PASL & 0,786523 & 0,52514 & 0,54905 \\
BW & 0,781943 & 0,03853 & $-0,46792$ \\
PL & 0,843029 & $-0,5424$ & 0,26291 \\
CPD & 0,868093 & $-0,1662$ & $-0,45938$ \\
NVS & 0,52 & $-0,823857$ & 0,576103 \\
NAFL & 0,72 & $-0,488551$ & $-0,87860$ \\
\hline Variance & - & $\mathbf{1 0 6}$ & $\mathbf{2 0 , 6}$ \\
\hline
\end{tabular}

Tabel 2. Hasil klasifikasi analisis deskriminan stepwise untuk karakter morfometrik dan meristik Table 2. Classification result of stepwise discriminant analysis for morphometric and meristic characters

\begin{tabular}{|c|c|c|c|c|c|c|c|c|c|}
\hline \multirow{2}{*}{$\begin{array}{l}\text { Kelompok/ } \\
\text { Group }\end{array}$} & \multirow{2}{*}{$\mathbf{N}$} & \multirow{2}{*}{$\begin{array}{l}\text { Persen benar/ } \\
\text { Validity }\end{array}$} & \multicolumn{7}{|c|}{$\begin{array}{l}\text { Klasifikasi kelompok populasi ikan belida (Chitala spp.)/ } \\
\text { Group classification of knife fish (Chitala spp.) population }\end{array}$} \\
\hline & & & Kerc & KKI & TK & RK & Kelek & PB & OG \\
\hline \multicolumn{10}{|l|}{ Morfometrik } \\
\hline Kerc & 9 & 88,9 & 8 & - & - & 1 & - & - & - \\
\hline KKI & 6 & 66,7 & - & 4 & 1 & 1 & - & - & - \\
\hline TK & 4 & 100 & - & - & 4 & - & - & - & - \\
\hline RK & 34 & 91,2 & 1 & - & - & 31 & - & - & 2 \\
\hline Kelek & 8 & 87,5 & - & - & - & - & 7 & - & 1 \\
\hline PB & 16 & 100 & - & - & - & - & - & 16 & - \\
\hline$O G$ & 3 & 100 & - & - & - & - & - & - & 3 \\
\hline total & 80 & 91,2 & - & - & - & - & - & - & - \\
\hline \multicolumn{10}{|l|}{ Meristik } \\
\hline Kerc & 13 & 0 & - & 9 & - & 3 & 1 & - & - \\
\hline $\mathrm{KKI}$ & 33 & 75,8 & - & 25 & - & 6 & - & 2 & - \\
\hline TK & 6 & 0 & - & 3 & - & 3 & - & - & - \\
\hline RK & 39 & 82,0 & - & 6 & - & 32 & - & 1 & - \\
\hline Kelek & 7 & 0 & - & 6 & - & 1 & - & - & - \\
\hline PB & 16 & 87,5 & - & - & - & 2 & - & 14 & - \\
\hline PLTA & 5 & 0 & - & 5 & - & - & - & - & - \\
\hline Total & 119 & 40,3 & & & & & & & \\
\hline
\end{tabular}


Perbedaan yang nyata dari group centroid dikonfirmasi dari plot 1 dan 2 canonical variate (Gambar 3), mewakili 88,8 dan $18,6 \%$ dari data yang ada (Tabel 1). Meskipun terdapat overlaping namun, populasi ikan belida (Chitala spp.) yang ada di pangkalan Buluh terlihat terpisah dapat dibedakan dengan kelompok yang lain. Dendogram yang dibuat dari analisis cluster berdasarkan pada karakter morfometrik juga memperlihatkan jarak genetik yang besar dari populasi ikan Pangkalan Buluh (Musi) dan beberapa populasi Musi yang lain (Gambar 4).

Ada hubungan kekerabatan (diperlihatkan dengan kemiripan morfometrik dari hasil analisis klasifikasi) dan keterpisahan kelompok berkaitan erat dengan sejarah biogeografi. Populasi ikan belida (Chitala spp.) yang dahulu merupakan 1 populasi, kemudian menjadi populasi yang terpisah dan terisolasi antara lain Pulau Sumatera dan Kalimantan, karena naik permukaan air laut akibat mencair es pada zaman pleistocen. Populasi yang terisolasi kemudian mengalami perubahan genotip dan atau fenotip, khususnya sifat adaptif yang berkembang melalui seleksi alam, sebagai respon kondisi lingkungan yang berbeda pada daerah yang secara geografi terpisah. Selanjutnya pengaruh lingkungan, seleksi, dan genetik pada tahap ontogeny individu menyebabkan perbedaan morfometrik di dalam suatu spesies (Cardin \& Friedland, 1999; Poulet et al., 2005).

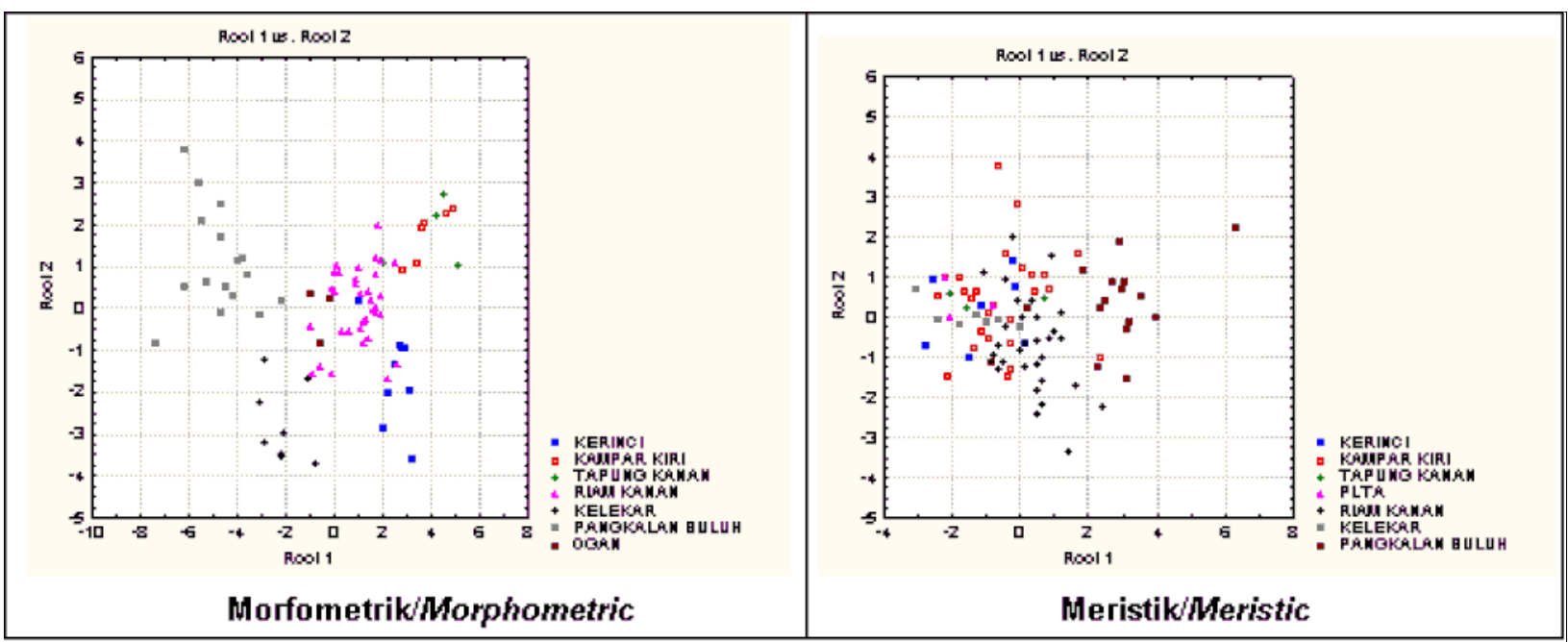

Gambar 3. Plot individual dan group centroid pada canonical variabel 1 dan 2 untuk 7 populasi ikan belida (Chitala spp.) berdasarkan pada karakter morfometrik dan meristik.

Figure 3. Individual plot and centroid group on canonical variabel 1 and 2 for 7 population knife fish (Chitala spp.) based on morfometric and meristic characters.

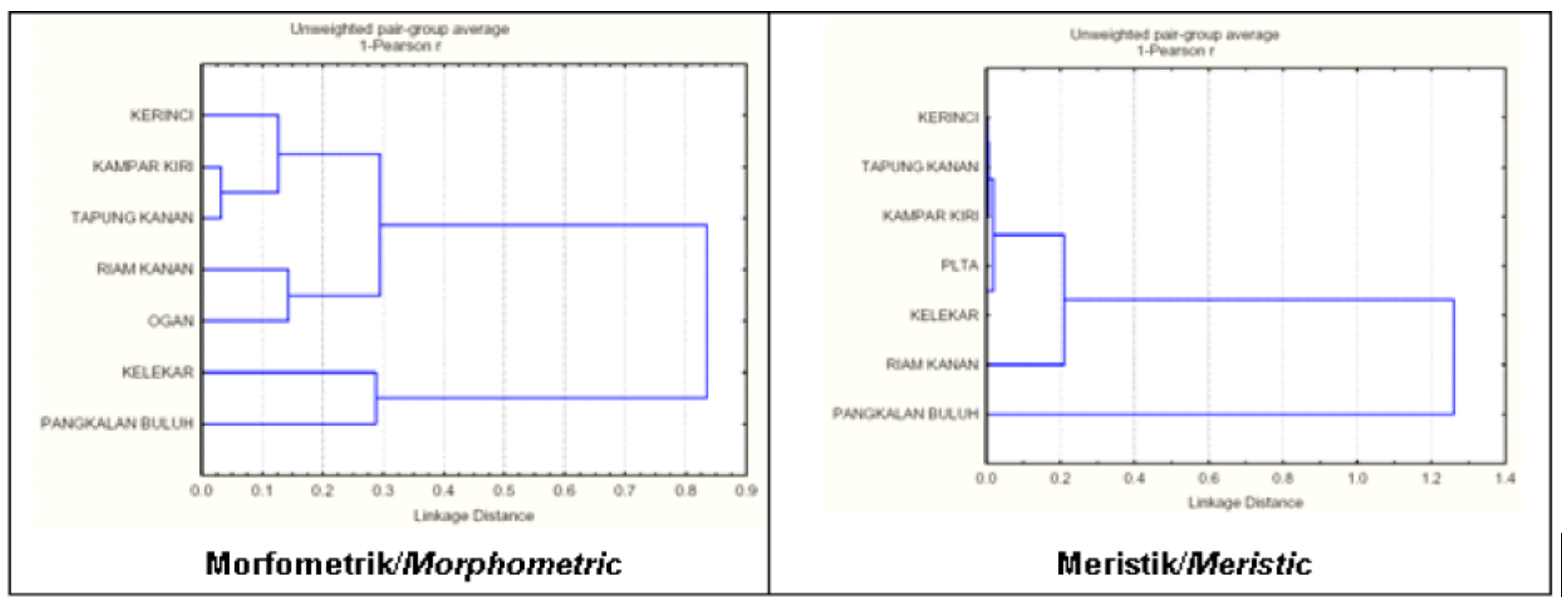

Gambar 4. Dendogram dibuat berdasarkan pada analisis cluster mahalobis distance untuk karakter morfometrik dan meristik.

Figure 4. Dendogram made base on cluster analysis mahalobis distance for morphometric and meristic characters. 


\section{Analisis Meristik}

Analisis stepwise memperlihatkan bahwa 2 dari 4 karakter meristik memberikan kontribusi yang nyata terhadap deskriminan multivariate dari 7 populasi ikan belida (Chitala spp.) yang diamati (Tabel 1). Tingkat pengelompokkan populasi dari prosedur klasifikasi silang pada 2 karakter diperkirakan berkisar antara 0 sampai dengan $87,5 \%$ dengan rata-rata $40,3 \%$ (Tabel 2). Berdasarkan pada hasil analisis karakter meristik, populasi ikan belida (Chitala spp.) yang ada di Pangkalan Buluh (Musi) memiliki tingkat validitas yang paling besar memperlihatkan ada isolasi spesies yang sempurna.

Perbedaan yang nyata dari group centroid dikonfirmasi dari plot 1 dan 2 canonical variate (Gambar 3), mewakili hanya 17,2 dan 2,0\% dari data yang ada (Tabel 1). Seperti juga hasil morfometrik, hasil analisis terhadap karakter meristik memperlihatkan populasi ikan belida (Chitala spp.) di Pangkalan Buluh terlihat terpisah dapat dibedakan dengan kelompok yang lain, sedangkan ikan belida (Chitala spp.) yang berasal dari populasi Riau ada kecendrenguan mengelompokkan atau memiliki jarak genetik yang kecil. Dendogram yang dibuat dari analisis cluster berdasarkan pada karakter morfometrik (Gambar 4) juga memperlihatkan jarak genetik yang besar dari populasi ikan belida (Chitala spp.) di Pangkalan Buluh, hasil yang berbeda diperlihatkan pada populasi di Riau.

Tidak ada satupun karakter meristik yang dapat membedakan populasi secara jelas, namun demikian NVS dan NAFL memperlihatkan nilai indeks potensi yang lebih superior. Dapat dikatakan bahwa karakter tersebut adalah karakter utama yang membedakan 7 populasi ikan belida (Chitala spp.) yang diamati. NVS memperlihatkan nilai korelasi yang terbesar dengan fungsi canonical variate 1 , sedangkan NAFL pada fungsi canonical2. Populasi Musi (pangkalan Buluh dan Kelekar) ditandai dengan nilai NVS yang besar dan NAFL yang kecil.

Analisis morfometrik dan meristik memperlihatkan bahwa populasi ikan belida (Chitala spp.) yang ada di Riau memiliki jarak genetik yang dekat satu sama lain (Pembangkit Listrik Tenaga Air, Kampar Kiri, Tapung Kanan, dan Kerinci), hal ini disebabkan oleh kedekatan geografis yang memungkinkan terjadi aliran gen dan kondisi lingkungan yang relatif sama (air hitam bersifat masam).

Jarak genetis yang terbesar terdapat antara populasi Pangkalan Buluh (Musi) dengan populasi yang lain, hasil ini erat kaitan dengan ada isolasi geografis dan pengaruh lingkungan, habitat populasi ini berbeda (air kuning coklat bersifat basa). Menurut Turan et al. (2004) tingkat isolasi yang cukup dengan wilayah geografis yang terbatas dapat menghasilkan perbedaan morfologi, meristik, dan genetik yang nyata antara lain stok atau populasi dalam spesies yang sama karena tidak ada aliran gen antara populasi tersebut. Selain isolasi geografis, pengaruh lingkungan juga menyebabkan tampilan fenotip yang berbeda. Turan et al. (2004) mengatakan bahwa faktor lingkungan dapat menyebabkan perubahan fenotip pada ikan. Sifat plastisitas yang dimiliki ikan membuat dapat memberi tanggapan secara adaptif pada perubahan lingkungan dan kondisi lingkungan yang ada dengan cara melakukan modifikasi fisiologi dan perilaku, hal ini akan membawa pada perubahan morfologi, reproduksi, atau kemampuan bertahan hidup yang disebabkan oleh pengaruh lingkungan (Stearns, 1983; Jawad, 2001).

\section{Variasi Genetik Ikan Belida (Chitala spp.)}

Secara umum, panjang mitokondria-DNA daerah 16sr Rna untuk ikan belida (Chitala spp.) berkisar antara 660 sampai dengan 1.050 bp. Dari 6 enzim restriksi yang digunakan yaitu Taq 1 , Nde II, Alu I, Hae III, Hind III, dan Rsal hanya 4 yang memotong fragmen daerah mitokondria-DNA yang diamplifikasi (Gambar 5). Ke-4 enzim tersebut adalah Taq I, Nde II, Alu I, dan Hae III. Enzim Taq I mempunyai hasil pemotongan yang polymorfik berupa 3 tipe restriksi, sedangkan 3 enzim lain mempunyai pola pemotongan yang monomorfik. Enzim Taq I mempunyai kemampuan untuk digunakan sebagai marker pembeda antara ikan belida (Chitala spp.). Berdasarkan pada hasil restriksi enzim tersebut didapatkan bahwa ikan belida (Chitala spp.) mempunyai haplotype \#1 dan \#4.

Besaran variasi genetik ikan belida (Chitala spp.) ditunjukkan oleh nilai diversitas haplotype, berdasarkan pada pola pemotongan 4 enzim retriksi, didapatkan variasi genetik ikan belida (Chitala spp.) berkisar antara 0 (populasi Sungai Kampar Kiri, Ogan, dan Kerinci) sampai dengan 0,125 (Sungai Kampar Kanan). Nilai diversitas haplotype ini relatif rendah jika dibandingkan ikan-ikan air tawar lain, misal ikan nila. Fenomena ini terjadi disebabkan oleh populasi yang kecil dan tidak ada aliran gen, karena isolasi geografis. Populasi kecil terjadi karena ekploitasi ikan belida (Chitala spp.) yang berasal dari hasil tangkapan alam, karena upaya domestikasi dan budi daya belum banyak berhasil dilakukan, tidak terjadi aliran gen akibat ada fragmentasi antara habitat sungai dan kecil peluang mengadakan persilangan dengan populasi 
dari daerah lain sehingga untuk populasi-populasi ikan belida (Chitala spp.) tertentu tidak dapat berkembang.

Mustafa (1999) menyatakan bahwa variasi genetik yang rendah terlihat pada ikan yang jarang atau dilindungi (memiliki jumlah populasi yang sedikit). Ikan yang memiliki populasi yang sedikit cenderung mengalami efek populasi bottleneck (turun populasi efektif) dan tekanan silang dalam (Allendorf et al., 1987; Mustafa, 1999). Tekanan silang dalam yang terjadi pada populasi kecil, mengakibatkan hilang allele resesif di populasi tersebut yang menghasilkan tidak kematian lebih cepat tapi juga suatu penurunan kesuburan atau tingkat pertumbuhan (Galbusera et al., 2000). Isolasi geografis memberikan kontribusi berkurangnya variasi genetik, populasi yang terisolasi cenderung mengurangi variasi genetik, sebagai akibat berpengaruh pada kemampuan untuk beradaptasi terhadap variasi lingkungan, untuk kemudian membatasi pilihan evolusi (Meffe \& Carroll, 1994). Selain itu, isolasi juga menyebabkan tidak terjadi aliran gen (gene flow), dalam hal ini diasumsikan aliran gen dapat mempertahankan dan menambah variasi genetik suatu populasi (Turan et al., 2004).

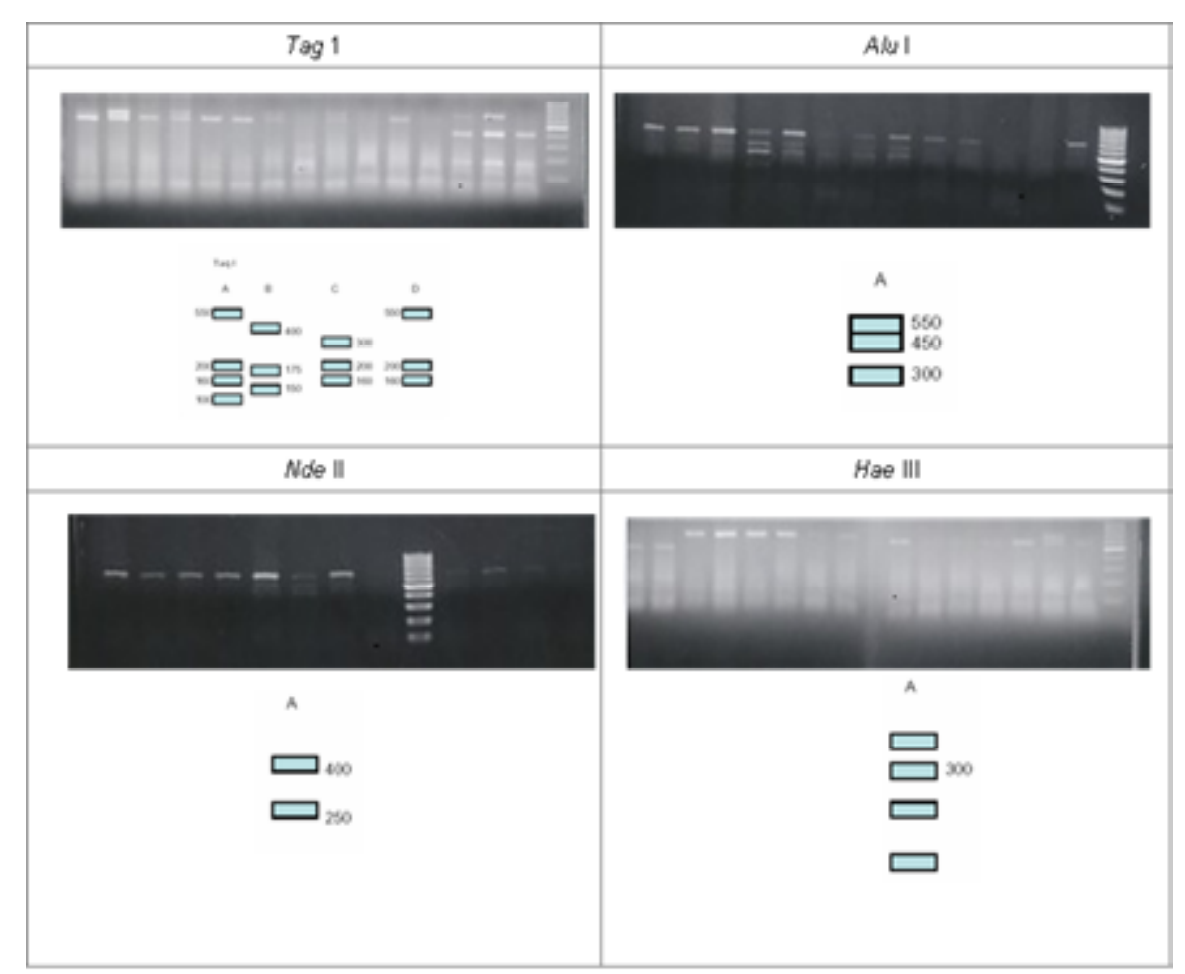

Gambar 5. Pola restriksi yang dibentuk oleh enzim Taq I, Nde II, Alu I, dan Hae III. Figure 5. Restriction pattern made by enzim Taq I, Nde II, Alu I, dan Hae III.

Keragaman genetik adalah dasar untuk terjadi proses fleksibilitas evolusi sebagai respon atau tanggapan spesies terhadap perubahan lingkungan (Allendorf et al., 1987; Meffe \& Carroll, 1994; Mustafa, 1999; Turan et al., 2004). Populasi dengan variasi genetik yang rendah (seragam) diperlihatkan antara lain level endogamy (abnormalitas) yang tinggi, pada umumnya memperlihatkan fitness yang tertekan, khususnya berkaitan dengan faktor kesuburan, pertumbuhan, dan survival (Leberg, 1990), tingkat yang rendah dari faktor-faktor ini akan merusak kemampuan suatu populasi untuk beradaptasi terhadap perubahan lingkungan. Sebagai contoh Cheetah Afrika Acinomyx jubatus jubatus memiliki allozyme loci yang tidak umum sebagai hasil dari tekanan silang dalam dan efek boottleneck yang parah (O'brien et al., 1983; 1985).

Hasil perhitungan jarak genetik menunjukkan bahwa populasi Sungai Kampar Kiri, Ogan, dan Kerinci mempunyai jarak genetik yang terdekat. Jarak genetik terjauh terjadi antara populasi ikan belida (Chitala spp.) dari Sungai Kampar Kiri dan Kampar Kanan. Lebih jauh, ternyata populasi ikan belida (Chitala spp.) Sungai Kampar Kiri hanya mempunyai 1 type haplotype, sedangkan populasi ikan belida (Chitala spp.) dari Sungai Kampar Kanan contoh yang diuji mempunyai 2 type haplotype. Hasil analisis nilai Fst berpasangan menunjukkan bahwa tidak terdapat perbedaan genetik secara statistik 
$(\mathrm{P}>0,05)$ antara lain ikan belida (Chitala spp.) yang diuji. Perbedaan yang terbesar terjadi antara ikan belida (Chitala spp.) dari populasi Kelekar dan Kampar Kiri, sedangkan perbedaan yang kecil bahkan tidak ada variasi terjadi antara ikan belida (Chitala spp.) dari populasi Sungai Kampar Kiri, Ogan, dan Kerinci.

Hasil dendrogram (Gambar 6) berdasarkan pada frekuensi haplotype dari 4 enzim restriksi menunjukkan, terdapat 5 kelompok populasi ikan belida (Chitala spp.) yaitu kelompok 1 terdiri atas populasi Sungai Ogan (Musi), Kerinci, dan Sungai Kampar Kiri, kelompok 2 Waduk Riam Kanan, kelompok 3 Waduk Pembangkit Listrik Tenaga Air Kuto Panjang, kelompok 4 terdiri atas Sungai Kelekar, dan Sungai Kampar Kanan, dan Kelompok 5 Tapung Kanan (Siak) dan Pangkalan Buluh (Musi). Pengelompokkan ini sebagian sesuai dengan keadaan geografi, namun sebagian tidak, hal ini mengindikasikan ikan belida (Chitala spp.) yang berada pada lokasi penelitian memperlihatkan memiliki keturunan yang sama (sejarah Paparan Sunda). Namun, demikian pengaruh lingkungan dan fragmentasi habitat menyebabkan mulai terbentuk populasi yang terpisah.

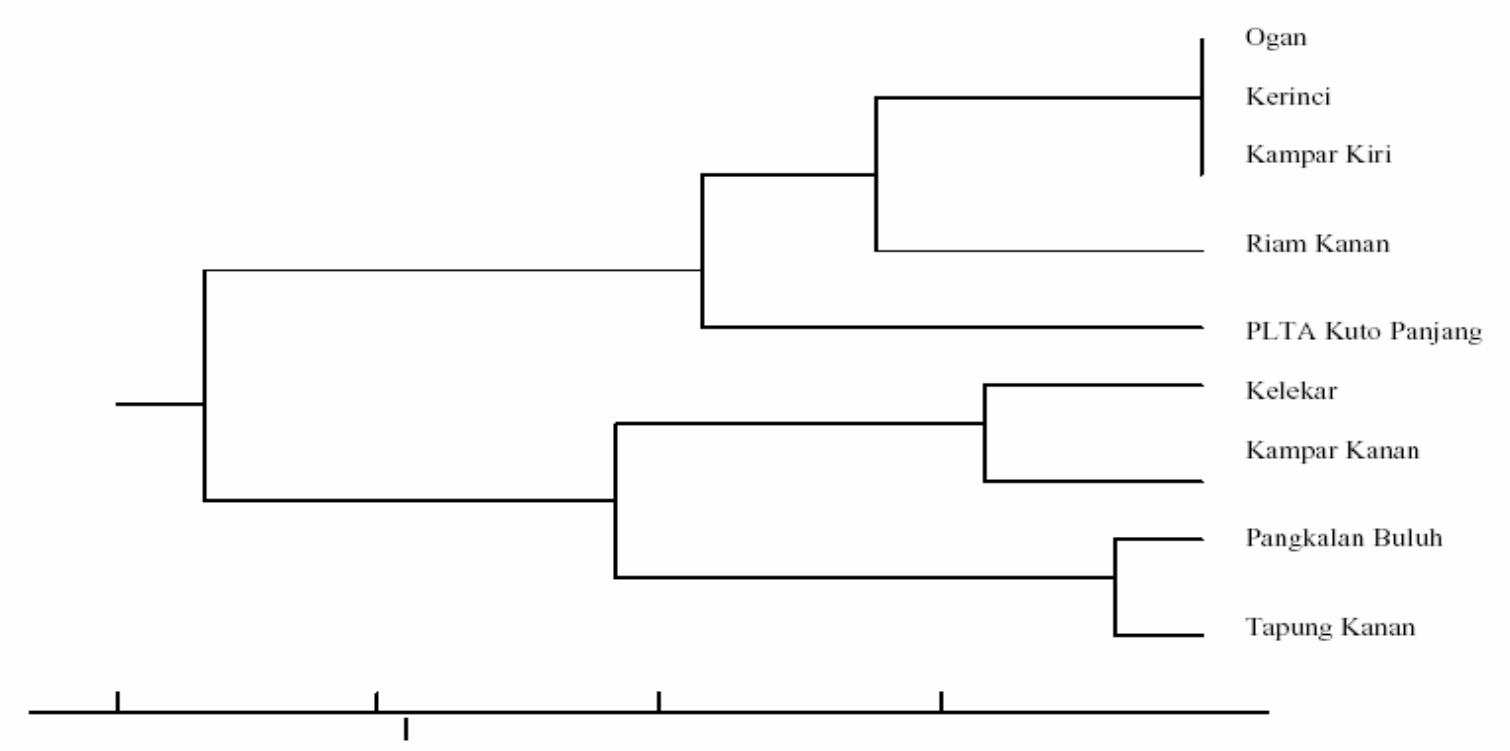

Gambar 6. Dendogram jarak genetik berdasarkan pada frekuensi haplotype dari 4 enzim restriksi.

Figure 6. Dendogram genetic distance based on haplotype frequency derived from 4 restriction enzim.

\section{Implikasi Konservasi dan Manajemen Populasi Ikan Belida (Chitala spp.) di Alam}

Data genetik mengatakan bahwa keragaman genetik ikan belida (Chitala spp.) tergolong rendah dengan kisaran antara 0 sampai dengan 0,125, sehingga konservasi menjadi sesuatu yang penting bagi spesies ini. Konservasi ikan belida (Chitala spp.) terutama diprioritaskan pada populasi yang terdapat di Sungai Kampar Kiri, Ogan, dan Kerinci, berdasarkan pada jumlah populasi yang kecil dan kondisi keragaman genetik populasi yang seragam. Lynch et al (1995) memperlihatkan bahwa populasi kecil memiliki kemungkinan besar terhadap menurunnya fitness karena akumulasi mutasi yang mengganggu. Hendrik et al. (1996) mengatakan bahwa variasi yang rendah dalam suatu spesies menjadi indikasi terjadi populasi bottleneck dan kondisi bottleneck menyebabkan kepunahan melalui tekanan silang dalam. Pada populasi yang kecil, genetic drift cenderung mengurangi variasi genetik, membawa pada kondisi akhir homozigot dan hilang kemampuan adaptasi evolusi terhadap perubahan lingkungan (Lande, 1988).

Data Morfologi (morfometri dan meristik) mengindikasikan peran lingkungan yang besar pada populasi ikan belida (Chitala spp.) yang diamati, perbedaan genetik terlihat kecil pada kondisi lingkungan yang dekat dan sama; sebagai contoh populasi Riau dan Musi (Kelekar, Ogan, dan Pangkalan Buluh). Lingkungan akan membuat keragaman genetik menjadi terseleksi, di mana genotip yang dipakai untuk adaptasi akan tetap ada 
dan yang tidak dipakai akan hilang, kondisi keragaman yang rendah akan mempercepat kepunahan ikan ini sehingga menjadi peningkatan keragaman genetik ikan ini benar-benar menjadi sesuatu yang penting.

Upaya konservasi yang dapat dilakukan pada populasi-populasi ini adalah dengan menambah jumlah populasi melalui translokasi, kebijakan translokasi berdasarkan pada data kedekatan genetik di mana populasi yang digunakan untuk restocking adalah populasi ikan belida (Chitala spp.) yang berasal dari Waduk Kuto Panjang. Selain Populasi Kuto Panjang, sebenarnya populasi Waduk Riam Kanan dapat digunakan, namun ada haplotip unik dan spesifik pada populasi Riau membuat usaha restocking sangat beresiko mengakibatkan erosi genetik.

Translokasi terbukti berhasil meningkatkan populasi efektif dan keragaman genetik salmon (Salvanicus namaychus) (Piller et al., 2005). Menurut Griffith et al. (1989); Wolf et al. (1996), translokasi hewan seringkali digunakan untuk restocking atau menambah populasi yang telah menurun. Translokasi menjadi penting untuk meminimalisasi ancaman genetik yang terus berlangsung seperti isolasi, fluktuasi lingkungan dan kerentanan terhadap bencana dan berkurangnya populasi. Peningkatan jumlah populasi di alam dari restocking tidak memberikan ancaman terhadap sumber daya genetik, malahan penambahan dari budi daya akan membantu menjaga keragaman genetik yang hilang atau terancam tanpa interpretasi. Namun, demikian kebijakan atau perencanaan translokasi berdasarkan pada identifikasi unit konservasi berdasarkan pada jarak genetik dan struktur genetik (Moritz, 1994; Johnson et al., 2001). McCracken et al. (2000), menambahkan struktur genetik adalah elemen yang penting tidak hanya menggambarkan struktur populasi, namun juga disadari menjadi sesuatu yang penting untuk keefektifan dan keberhasilan upaya manajemen.

Apabila perencanaan restocking tidak mempertimbangkan kondisi genetik, besar kemungkinan akan terjadi kegagalan, material genetik spesies introduksi merusak gen kompleks adaptasi (Templeton, 1986) atau mengurangi sifat yang dapat beradaptasi terhadap lingkungan lokal, populasi dapat mengarah pada kepunahan (Greig, 1979). Hal ini, terjadi pada spesies asli fisher (Martes pennanti), di mana terjadi penggantian material genetik spesies asli fisher (Martes pennanti) akibat translokasi melalui Genetik drift (Drew et al., 2003). Keberhasilan translokasi dapat dilihat melalui kondisi gen pool, jika berhasil maka akan terjadi percampuran antara spesies asli dengan spesies atau genotip yang diintroduksi, spesies introduksi memperkaya spesies asli (Storfer, 1999).

Upaya restocking selain mengambil dari populasi yang sudah alami (misal 7 populasi yang ada) dapat juga melalui pembuatan spesies sintetik untuk kemudian direstocking ke populasi alam. Namun, untuk keberhasilan pembuatan populasi sintetik perlu design persilangan berdasarkan pada kemiripan penyusun genetik yang sama dan program reintroduksi tidak hanya memperhitungkan asal individual secara geografi, namun juga penyusun genetik. Berdasarkan pada data genetik populasi sintetik dapat dari persilangan antara populasi yang termasuk dalam 1 kelompok seperti yang telah disebutkan sebelumnya. Manfaat lain dengan ada peta gen akan mendorong keberhasilan breeding untuk keperluan budi daya, selanjutnya keberhasilan breeding akan memberikan kontribusi pada kegiatan konservasi ikan alam. Ada kegiatan budi daya akan mengurangi tekanan terhadap populasi alami dan muncul kesadaraan akan sumber genetik yang ada, karena ini diperlukan untuk kontinuitas budi daya, di mana stok alam dapat menyediakan sumber daya genetik baru dan cepat untuk mengatasi masalah keragaman genetik stok budi daya. Pada akhirnya, pola dan luas keragaman genetik yang ada di alam, perlu dimonitoring dan dilakukan dokumentasi, sehingga memiliki sejarah populasi melalui catatan kondisi keragaman genetik dan ada sifat genetik yang unik (Mather \& Bruyn, 2003).

Prioritas konservasi populasi ikan belida (Chitala spp.) selanjutnya adalah populasi Pangkalan Buluh (Musi), populasi ini ditandai oleh karakter morfometrik $\mathrm{AH}$ dan ISL yang besar dan PPFL yang kecil dan nilai NVS yang besar dan NAFL yang kecil pada karakter meristik. Penentuan prioritas ini didasarkan pada data genetik dan lebih jelas pada karakter morfometrik (terisolasi) yang mengungkapkan bahwa populasi Pangkalan Buluh adalah populasi yang terpisah dengan jarak genetik yang jauh dengan populasi yang lain dan diduga memiliki keragaman genetik yang unik. Konservasi menjadi prioritas pada saat jumlah populasi telah kecil dan memiliki endemic haplotipe (Mc Cracken et al., 2000). Upaya manajemen populasi Pangkalan Buluh memiliki pendekatan yang berbeda dengan Sungai Kampar Kiri, Sungai Ogan, dan Kerinci, di mana upaya yang terbaik adalah dengan penetapan lokasi konservasi dan membiarkan populasi berkembang, menurut Vrijenhoek (1998), ketika analisis genetik yang komprehensif mengatakan tidak ada perbedaan antar populasi dan bukti geografi menunjukkan terjadi 
fragmentasi, translokasi dapat menjadi jaminan sebagai penambahan populasi alami dan menghindari terjadi genetic drift dan inbreeding. Sebaliknya, ketika populasi dipisahkan secara geografi dan berbeda secara genetik, yang terbaik adalah membiarkan ikan asli dihabitat alami tanpa dilakukan restocking.

\section{KESIMPULAN}

1. Berdasarkan pada analisis genetik terdapat 5 kelompok populasi ikan belida (Chitala spp.) yaitu kelompok 1 terdiri atas populasi Sungai Ogan (Musi), Kerinci, dan Sungai Kampar Kiri, kelompok 2 Waduk Riam Kanan, kelompok 3 Waduk Pembangkit Listrik Tenaga Air Koto Panjang, kelompok 4 terdiri atas Sungai Kelekar dan Sungai Kampar Kanan dan Kelompok 5 Tapung Kanan (Siak) dan Pangkalan Buluh (Musi). Populasi Pangkalan Buluh adalah populasi yang unik, memiliki jarak genetik yang lebar dan terpisah dari populasi yang lain, berdasarkan pada data genetik dan lebih jelas pada morfologi baik meristik maupun morfometrik. Populasi ini ditandai oleh karakter morfometrik AH dan ISL yang besar dan PPFL yang kecil dan nilai NVS yang besar dan NAFL yang kecil pada karakter meristik.

2. Keragaman genetik populasi ikan belida (Chitala spp.) di lokasi pengamatan tergolong rendah dengan kisaran antara 0 sampai dengan 0,125. Konservasi ikan belida (Chitala spp.) terutama diprioritaskan pada populasi yang terdapat di Sungai Kampar Kiri, Sungai Ogan, dan Kerinci, prioritas selanjutnya adalah populasi Pangkalan Buluh (Musi). Pendekatan konservasi yang dilakukan memiliki pendekatan yang berbeda, upaya konservasi pada populasi Sungai Kampar Kiri, Sungai Ogan, dan Kerinci adalah dengan translokasi atau restocking, sedangkan untuk Pangkalan Buluh adalah penetapan wilayah konservasi sehingga populasi dapat berkembang tanpa restocking. Data genetik juga menyediakan peta gen untuk perencanaan design persilangan untuk restocking, populasi sintetik, dan program breeding ikan belida (Chitala spp.) di lokasi penelitian.

\section{UCAPAN TERIMA KASIH}

Penulis mengucapkan terima kasih pada mbak Eti, Komang, Krisna Kumari, Syamsul Bahri, Ahmad Syahyani, dan pihak-pihak lain yang telah membantu kegiatan penelitian ini sepanjang tahun 2006.

\section{PERSANTUNAN}

Kegiatan dari hasil riset karakteristik habitat dan keragaman jenis ikan belida (Chitala spp.) di perairan umum Indonesia, T.A. 2006, Balai Riset Perikanan Perairan Umum, Mariana-Palembang.

\section{DAFTAR PUSTAKA}

Al-Hassan L. A. J. 1984. Meristic comparison of Liza $a b u$ from Basrah. Iraq and Karkhah River. Arabistan. Iran. Cybium. 8. 3. p.107-108.

Allendorf, F., N. Ryman, \& F. Utter. 1987. Genetic and fishery management: Past, present and future in population genetic and fishery management $\mathrm{Ed}$. Nils Ryaman and Fred Utter. University of Washington Press. USA. 1-18 pp.

Amos B. \& A. R. Hoelzel. 1992. Applications of molecular genetic techniques to the conservation of small populations. Biological Conservation. 6. p.133-144.

Beacham, T. D., R. E. Withler, \& A. P. Gould. 1985a. Biochemical genetic stock identification of pink salmon (Oncorhynchus gorbuscha) in southern British Columbia and Puget Sound. Canadian Journal of Fisheries and Aquatic Sciences. 42. 1. p.474-1483.

Beacham, T. D., R. E. Withler, \& A. P. Gould. 1985b. Biochemical genetic stock identification of chum salmon (Oncorhynchus keta) in southern British Columbia. Canadian Journal of Fisheries and Aquatic Sciences. 42. p.437-448.

Brown W. M., M. George, \& A. C. Wilson. 1979. Rapid evolution of mitochondrial DNA. Proc. Natl Acad. Sci. USA. 76. p.1967-71.

Brown W. M. 1983. Evolution of animal mitochondrial DNA. pp 62-88. In M. Nei \& R. K. Koehn (eds). Evolution of Genes and Proteins. Sinauer. Sunderland. M. A.

Crandall, K. A., J. W. Fetzner Jr, S. H. Lawler, M. Kinnersley, \& C. M. Austin. 1999. Phylogenetic relationships among the Australian and New Zealand genera of freshwater crayfishes (Decapoda: Parastacidae). Australian Journal Zoology. 47. p.199-214. 
Clayton, R. R. \& H. R. Mac Crimmon. 1987. Partitioning size from morphometric data: A comparison of five statistical prosedurs used in fisheries stock indentification research. Can. Tehn. Rep. Fish. Aq. Serv. 1531. p.1-23.

Drew, R. E., J. G. Hallett, K. B. Aubry, K. W. Cullings, S. M. Koepf, \& W. J. Zielinski. 2003.Conservation genetics of the fisher (Martes pennanti) based on mitochondrial DNA sequencing. Molecular Ecology. 12. p.51-62.

Fisher, R. A. 1936. The use of multiple measurements in taxonomic problems. The Annals of Eugenics. 7. p. $179-188$.

Galbusera, P., L. Lens, T. Schnenck, E. Waiyaki, \& Matthysen. 2000. Genetic variability and gene flow in the globally, critically endangered Taita thrush. Conservation Genetics. 1. p. 45-55.

Greig, J. C. 1979. Principles of genetic conservation in relation to wildlife management in southern Africa. South African Journal of Wildlife Research. 9. p. 57-78.

Griffith, B., M. J. Scott, J. W. Carpenter, \& C. Reed. 1989. Translocation as a species conservation tool: Status and strategy. Science. 245. p. 477480.

Gustiano, R. 2003. Taxonomy and phylogeny of Pangasiidae Catfishes from Asia (Ostariophysi, Siluriformes). Thesis for the Doctor's Degree (Ph.D.). Katholieke Universiteit Leuven. Leuven. Belgium. 296 p.

Harrison, R. G. 1989. Animal mitochondrial-DNA as a genetic marker in population and evolutionary biology. Trends in Evolutionand Ecology. 4. p. 611.

Hedrick, P. W., R. C. Lacy, F. W. Allendorf, \& M. E. Soule. 1996. Population bottleneck. Conservation Biology. 10. 1312 p.

Jawad, L. A. 2001. Variation in meristic characters of a tilapian fish, Tilapia zilli (Gervais, 1848) from the inland Water bodies in Libya. Acta Ichthyol. Piscat. 31 (1). p. 159-164.

Johnson, W. E., E. Eizirik, M. Roelke-Parker, \& S. J. O' Brien. 2001. Applications of genetic concepts and molecular methods to carnivore conservation. In Carnivore Conservation (eds
Gittleman J. L., Funk S. M., Macdonald D., \& Wayne R. K.). p. 335-358. Cambridge University Press. London.

Kottelat, M. \& E. Widjanarti. 2005. The fishes of Danau Sentarum national park and Kapuas Lake area, West Borneo. The Raffles Bulletin Zoology. Supplemental 13. p. 139-173.

Krueger, C. C. 1986. Incorporation of the stock concept into fisheries management. Paper Presented at the Symposium Fisheries Genetics: Today and Tomorrow. 1986. Annual Meeting of the American Fisheries Society. Providence. R. I.

Lande, R. 1988. Evolutionary biology. Science. 241. p. 1.455-1.459.

Lynch, M., J. Conery, \& R. Burger. 1995. Genetic in small population. Am. Nat. 146. p. 489-495.

Leberg, P. L. 1990. Influence of genetic variability on population growth: Implications for conservation. Journal Fisheries Biology. 37. 193-195.

Mac Crimmon, H. R. \& R. R. Clayton. 1985. Meristic and morphometric identity of baltic stocks of Atlantic salmon (Salmo solar). Canadian Journal ZooLogy. 63. p. 2.032-2.037.

Manly, B. F. 1989. Multivariate statistical methods: A primer. Chapman \& Hall. New York. 423 p.

Mather, P. B \& M. de Bruyn. 2003. Genetic diversity in wild stocks of the giant freshwater prawn (Macrobrachium rosenbergii): Implications for aquaculture and conservation. NAGA. World Fish Center Quarterly. 26. p. 1-4.

May, R. M., J. H. Lawton, \& N. E. Stock. 1994. Population genetic of Atlantic salmon (Salmo solar). In Extinction Rate, J. H. Lawton \& R. M. May (Eds.). Oxford University Press. Oxford.

Mc Cracken, K. G, P. W. Johnson, \& F. H. Sheldon. 2000. Molecular population genetics, phylogeography, and conservation biology of the mottled duck (Anas fulvigula). Conservation Genetics. 2. p. 87-102.

McGlade, J. M. \& E. Boulding. 1985. The truss: A geometric and statistical approach to the analysis of form in fish. Can. Tech. Rep. Fish. Aquacult. Sci. (147). p. 34-55. 
Meffe, G. K. \& R. Caroll R. 1994. Genetics: Conservation of diversity within species. In Sinauer Associates (ed). Principles of Conservation Biology. Sunderland. M. A. p. 143-178.

Moritz, C. 1994. Applications of mitochondrial-DNA analysis in conservation: A critical review. Molecular Ecology. 3. p. 401-411.

Mustafa, S. 1999. Genetic in sustainable fisheries management. Fishing Newbooks. London. 223 p.

Nei, M. \& F. Tajima. 1981. DNA polymorphism detectable by restriction endonucleases. Genetics. 97. p. 145-163.

O'Brien, S. J., D. Goldman, C. R. Merril, M. Bush, \& D. E Wildt. 1983. The cheetan is depauperate in biochemical genetic variation. Science. 221. 459462.

O'Brien, S. J., M. E. Roelke, L. Marker, A. Newman, C. A. Winkler, D. Meltzer, L. Colly, J. F. Everman, M. Bush, \& D. E Wildt. 1985. A genetic basis for species vulnerability in the cheetah. Science. 227. p. 1.428-1.434.

Pääbo, S. 1989. Ancient DNA: Extraction, characterization, molecular cloning, and enzymatic amplification. Proceedings of theNational Academy of Sciences. USA. 86. p. 1939-1943.

Piller, K. L., C. C.Wilson, C. E. Lee, \& J. Lyon. 2005. Conservation genetics of inland lake trout in the upper mississippi River Basin: Stocked or native ancestry?. Transactions of the American Fisheries Society. 134. p. 789-80.

Roberts, T. R. 1992b. Systematic revision of the old world freshwater fish family Noopteridae. Ichthyological Exploration of freshwaters. 2. p. 361-383.

Ryder, O. A., A. Mclaren, S. Brenner, Y. P. Zhang, \& K. Benirschke. 2000. Science. 124. p. 275-288.

Saraswati, P. K. \& S. V. Sabnis. 2006. Comparison of CART and discriminant analysis of morphometric data in foraminiferal taxonomy. Anuário do Instituto de Geociências. Indonesian Fisheries Research Journal. 29. p. 153-162.

Sarver, S. K., J. D. Silberman, \& P. J. Walsh. 1998. Mitochondrial-DNA sequence evidence supporting the recognition of two subspecies or species of the Florida spiny lobster Panulirus argus. Journal Crust. Biology. 18. (1). p. 177-186.

Schaeffer, K. M. 1991. Geografic variation in morphometric characters and gill-raker counts in yellow fin tuna (Tunnus albacares) from pacific ocean. Fish Buletin. 89. p. 289-297.

Seymour A. 1959. Effects of temperature upon the formation of vertebrae and fin rays in young chinook salmon. Trans. Amer. Fish. Soc. 88. p. 58-69.

Schneider, S., J. M. Kueffer, D. Roessli, \& L. Excoffier. 1996. Arlequin: A software package for population Genetic. University of Geneva. Geneva. Switzerland.

Sokal, R. R. \& F. J. Rohlf. 1995. Biometry: The principles and practice statistic biology research. $3^{\text {rd }}$ edition. W. H. Freeman. New York. 397p.

Sprent, P. 1972. The mathematics of size and shape. Biometrics. 28. p. 23-37.

Stearns, S. C. 1983. A natural experiment in life history evolution: Field data on the introduction of Mosquitofish (Gambusia affinis) to Hawaii. Evolution. 37. p. 601-617.

Storfer, A. 1999. Gene flow and endangered species translocations: A topic revisited. Biological Conservation. 87. p. 173-180.

Sudarto. 2003. Systematic revision and phylogenetic relationships among population of clariid species in Southeast Asia. Doctor Dissertation University of Indonesia. $371 \mathrm{pp}$.

Templeton, A. R. 1986. Coadaptation and outbreeding depression. In Conservation biology: The science of scarcity and diversity (ed. Soule ME). p. 105116. Sinauer Associates. Sunderland. M. A.

Tschibwabwa, S. M. 1997. Systematic of African species of genera Labeo (Telestei, Cyprinidae) in the ichthyological region of lower Guinea and Congo. PhD Dissertation. Namur.

Turan, C., E. Deniz, F. Turan, \& M. Ergüden. 2004. Genetic and morphologic structure of Liza abu (Heckel, 1843). Populations from the Rivers Orontes. Euphrates and Tigris. Turkish Journal Vet Anim Science. 28. p. 729-734. 
Vrijenhoek, R. C. 1998. Conservation genetics of freshwater fish. Journal of Fisheries Biology. 53 (Supplement A.). p. 394-412.

Waltner, C. M. 1988. Electhrporetic, morphometric, and meristic comparison of walleye broadstock in South Dakota. Thesis South Dakota State University. $86 \mathrm{p}$.
Wolf, C. M., B. Griffith, C. Reed, \& S. A. Temple. 1996. Avian and mammalian translocations: Update and reanalysis of 1987 survey data. Conservation Biology. 10. p. 1.142-1.154. 